UDC 351.72+37

DOI: $10.31110 / 2789-6536 / 2021-2 / 004$

\title{
General approaches to financing education in Ukraine: public administration
} aspect

\section{Postupna Olena}

Doctor of Science in Public Administration, Associate Professor, Associate Professor of the Department of Management of Training Research and Production Center, National university of civil defence of Ukraine

$$
\text { ORCID: 0000-0002-0622-0966 }
$$

\section{Stepanko Oleksii}

$\mathrm{PhD}$ in Public Administration, Head of Department for Material and Technical Support, National university of civil defence of Ukraine ORCID: 0000-0001-7691-4034

\footnotetext{
Abstract. The current economic situation does not meet educational needs, so most countries are changing the general approach to education funding, introducing targeted use of resources and diversification of funding sources, funding of educational institutions based on their performance and competitive processes, developing additional assistance packages for participants.

Ukraine finances education with the help of financial and economic methods, tools and incentives aimed at its development. Methods of direct (state order) and indirect influence are used (independent choice of business entities in education).

It is proved that the state and level of financing of education in Ukraine are significantly influenced by objective and subjective factors (global economic crisis in 2008, events of 2013-2014, foreign aggression, which continues up to this day in Ukraine, quarantine restrictions due to the announced COVID-19 pandemic in 2020). The state continues to use general approaches to education financing, however, in recent years an attempt has been made to introduce a new tool - the education
} 
subvention, which makes it possible to implement in education funding the budgetary principle of subsidiarity - the distribution of expenditures between state and local budgets. The principle of decentralization of management and financing of vocational (technical) education was also introduced. Now the share of the educational subvention is aimed at financing the salaries of educational institutions staff, as well as at improving the material and technical base of educational institutions and enhancing the quality of education.

Despite attempts to change the approach to the distribution of Ukraine's consolidated budget for education, its funding is insufficient and not fully effective, which requires the authorities to continue searching for new approaches to education funding.

Keywords: public management of education, decentralization, financing of education, educational subventions, budgetary principle of subsidiarity, sequestration of the state budget.

Introduction. Most of the countries affected by the financial crisis of 2008 and announced in 2020 COVID-19 pandemic caused by the SARS-CoV-2 now face serious economic and financial problems as a result of the suspension or partial closure of enterprises in various sectors of the economy, suspended tax and non-tax revenues to the state budget system, which is the main source of funding for education.

Thus, the current economic situation does not meet educational needs, so most countries are changing general approaches to education financing, such as the introduction of targeted use of resources and diversification of funding sources (grants, training on a contractual basis, commercialization of research, loans); financing of educational institutions on the basis of the results of their activities and competitive processes (for example, competition of projects for financing research), etc. Because of the COVID-19 pandemic, some countries have provided financial support to the participants of the educational process, mainly to those who obtain education. For instance, in Australia education aid packages were given (the 
government supported those who were laid off due to the crisis and sought to retrain or improve their skills (the cost of online courses was reduced); in Canada the government supported students and school leavers who could not find a job in the summer due to the pandemic situation (emergency assistance program); the Italian government supported distance learning by equipping schools with digital platforms and tools for online learning, as well as giving digital devices to low-income students, etc. [11].

An important achievement of Ukraine during the forced quarantine can be considered the introduction of the project "All-Ukrainian school online" in 2020 - the organization of the educational process remotely for high school students. Students received knowledge in 11 subjects, which were broadcast on Ukrainian TV channels and on the YouTube channel according to a clear schedule. Later, within the framework of this project, online broadcasting training was organized for primary school students (in mathematics, the Ukrainian language, science and art). In order to involve the majority of Ukrainian children in the educational process, Ukrainian stars (actors, musicians, presenters, athletes, etc.) were invited to participate in video lessons. Despite the measures taken, the crisis is only deepening in the field of education in Ukraine, mainly in the state of financial security. So, we are going to describe the general approaches to the financing of education in Ukraine and determine their public administration content.

The analysis of research and problem definition. Theoretical and practical aspects of public education management, definitions, characterization and improvement of public administration mechanisms, including economic and financial, are covered in the works of M. Azhazha, V. Beschastny, L. Belova, M. Bilynska, V. Bulba, L. Gayevska, L. Gren, N. Didenko, D. Karamyshev, N. Kolisnichenko, V. Kremen, V. Lugovoi, L. Parashchenko, L. Polyakova, L. Prokopenko, L. Khyzhnyak, I. Shpektorenko and others. Positively assessing the scientific achievements of these scientists, we believe that the current state and general approaches to the financing of education used in the educational practice of Ukraine have not been sufficiently reflected. 
The results of the research. The Ukrainian government finances education with the help of financial and economic methods, tools and incentives aimed at its development. The methods of direct (state order) and indirect influence (independent choice of business entities in the field of education) are used.

The basic educational legislation sets out the main provisions on financial and economic relations in the field of education. In particular, in Art. 78 it is emphasized that the state provides allocations for education in the amount of not less than $7 \%$ of GDP, financing of educational institutions is carried out at the expense of the state, local budgets and other sources of financing which are not forbidden by the legislation [6].

If we consider the field of education as a system consisting of different levels of education, it should be noted that the approach to their funding is not the same. According to the basic and special educational laws [4-8], the main source of funding for all levels of education, indeed, are the funds of the state and local budgets (for institutions of general secondary education of communal property and institutions of professional higher education - funds are provided by educational subvention and other transfers; for institutions of professional (vocational) education of state and communal property within the state and/or regional order; for institutions of higher education of state property on the terms of the state order). In addition, sources of funding are other funds which are not prohibited by law (profits for the provision of paid educational and other services by educational institutions (their list is approved by the government or the founders of relevant educational institutions, if services are not included in the list approved by the government); charity; targeted contributions of individuals and legal entities; funds of the founder(s) of the institution; grants, etc.).

There are following features of financing each level of education:

- in complete general secondary education - the educational subvention is directed to the pedagogical staff remuneration, and the funds of other transfers to educational institutions - for advanced staff training and provision with educational literature, equipment, teaching aids;

- in out-of-school education - socially protected categories of children 
obtain education free of charge (compensated by quotas from the state and/or local budgets); persons with special needs may gain education at the expense of educational subventions, state and/or local budgets and other sources;

- in vocational education - the amount of funding of state institutions cannot be reduced/ceased whereas other sources of funding are available; outstandings of the current year cannot be withdrawn from the account of the state institution;

- in professional pre-higher education - educational subvention is aimed at pedagogical staff remuneration, their advanced training; providing education in specialties with special support; providing education to people with special needs, etc.;

- in higher education - the size of budget allocations for the training of specialists/scientists is set by the State Budget of Ukraine for the relevant year; the total amount of the state order for the junior bachelor and bachelor degrees preparation for the current year makes not less than $51 \%$ of quantity of general secondary school leavers of the current year;

- in postgraduate education - the total amount of the state order for the Master degree training for the current year is not less than $50 \%$ of the number of people who will receive a bachelor's degree in the current year (for the Doctor of Philosophy degree - not less than $5 \%$ ).

The above mentioned indicates that although the main sources of funding for all levels of education are state and local budgets, educational institutions are also entitled to receive funds from additional sources not prohibited by law.

It should be noted that in the context of educational reform, financial security is a major factor in order to succeed. In this context, we will consider the changes that have taken place in the financing of education in Ukraine in recent years. However, first of all, it should be stated that the country's budget provides funds for education, which are used to implement relevant programs and activities. As mentioned above, the education budget consists of state and local budgets. Budget expenditures on education in Ukraine during 2012-2019 are given in Table 1. 
Tab. 1: Budget expenditures on education in Ukraine during 2012-2019

\begin{tabular}{|l|c|c|c|}
\hline \multicolumn{1}{|c|}{ The expenditure amount } & $\begin{array}{c}2012 \\
\text { (report) }\end{array}$ & $\begin{array}{c}2018 \\
\text { (report) }\end{array}$ & $\begin{array}{c}2019 \\
\text { (report) }\end{array}$ \\
\hline GDP & 1404,7 & 3560,6 & 3978,4 \\
\hline $\begin{array}{l}\text { Consolidated budget expenditures on education, } \\
\text { UAH billion }\end{array}$ & 101,6 & 210,0 & 238,8 \\
\hline Percentage of GDP & 7,2 & 5,9 & 6,0 \\
\hline State budget expenditures on education, UAH billion & 280,8 & 44,3 & 51,7 \\
\hline $\begin{array}{l}\text { The share of state budget expenditures on education } \\
\text { in the corresponding consolidated budget } \\
\text { expenditures, \% }\end{array}$ & 28,4 & 21,1 & 21,6 \\
\hline $\begin{array}{l}\text { Expenditures of local budgets on education, UAH } \\
\text { billion }\end{array}$ & 72,8 & 165,7 & 187,1 \\
\hline $\begin{array}{l}\text { The share of expenditures of local budgets on } \\
\text { education in the corresponding expenditures of the } \\
\text { consolidated budget, \% }\end{array}$ & 71,6 & 78,9 & 78,4 \\
\hline
\end{tabular}

Source: compiled by the authors based on $[1 ; 2 ; 9 ; 10 ; 12]$

The data in the table show significant changes in education budget expenditures. First of all, in the period from 2012 to 2020, the amount of GDP increased almost four times (in 2020, the amount of GDP is 4,194.1 billion UAH). Expenditures on the consolidated budget for education have more than doubled (in 2020, the amount amounted to 252.3 billion UAH). If we compare the percentage of education funding from GDP, there is a slight decrease - up to $6 \%$, which generally violates the Law of Ukraine "On Education" in the part of state provision of education in the amount of not less than $7 \%$ of GDP. It should be noted that in 2020 there was the largest amount of state budget expenditures which amounted to 52.9 billion UAH. The growth of local budget expenditures on education is also significant, in 2017 we could see its highest rate with 44.4\%. This growth is explained primarily by the fact that reforms of power and local self-government decentralization are being implemented in Ukraine, due to which there is a gradual transfer of power to the basic level of government - local, as well as the educational reform is progressing, which radically changes approaches to education.

In terms of education levels, the largest share of expenditures of the 
consolidated budget of Ukraine is traditionally directed to the development of complete general secondary education, its average share in expenditures for the period from 2014 to 2019 is $45.6 \%$ of the consolidated budget expenditures on education. The share of expenditures on higher education is twice lower $-24.5 \%$, and three times lower on preschool - $15.4 \%$. The smallest share (approximately $0.8 \%$ ) is the cost of postgraduate education [3, p. 199-203]. Since the introduction of a new education financing instrument, the education subvention, the share of the state budget has decreased by $4 \%$ and education expenditures from local budgets have decreased by $23 \%$ in recent years.

All of the above indicates a change in the role of state and local budgets in financing education. Today, local budgets come to the fore, based on the principles of subsidiarity and co-financing of education. Local authorities should take care of the effective development of the regional/local education system in order to ensure stable socio-economic development of their territory.

Let us dwell on a more detailed consideration of the state of financial and economic support of education in Ukraine. First of all, we will analyze changes in local budget expenditures on education, in accordance with its levels. Data for 20142019 are given as a percentage in Table 2.

Tab. 2: Changes in education expenditures of local budgets of Ukraine for 2014-2019, in percent

\begin{tabular}{|l|c|c|c|c|c|c|}
\hline \multicolumn{1}{|c|}{ Educational levels } & 2014 & 2015 & 2016 & 2017 & 2018 & 2019 \\
\hline Pre-school education & 15,1 & 15,8 & 15,4 & 15,8 & 15,1 & 15,1 \\
\hline General secondary education & 42,1 & 4,7 & 4,6 & 18,3 & 18,9 & 17,5 \\
\hline Extracurricular education & 4,2 & 4,1 & 4,1 & 4,2 & 4,2 & 4,2 \\
\hline Professional (vocational) education & 4,5 & 0,5 & 4,6 & 4,5 & 4,6 & 4,54 \\
\hline Higher Education & 2,8 & 2,6 & 2,6 & 2,4 & 3,6 & 3,5 \\
\hline Postgraduate education & 0,35 & 0,3 & 0,3 & 0,3 & 0,3 & 0,3 \\
\hline
\end{tabular}

Source: compiled by the authors based on $[1 ; 2 ; 9 ; 10 ; 12]$

The analysis of the given data testifies to instability in dynamics of expenses of local budgets. Expenditures on preschool, extracurricular, higher and postgraduate 
education can be considered stable expenditures during the examined period. At the same time, the highest level of funding for preschool education in Ukraine was observed in 2015 and 2017 and amounted to $15.8 \%$ of the total funding for education from local budgets. The level of funding for higher education increased by only $0.7 \%$. Since 2015 , there has been a decrease in funding of postgraduate education by $0.05 \%$. Although there is certain stability in the financing of these levels of education, at the same time the level of budgeting is too minimal, which does not allow educational institutions to function adequately and efficiently.

The situation with the financing of complete general secondary education is different. The indicators of local budget expenditures were significantly affected by the introduction of the education subvention in 2015: initially there was a sharp reduction in funding, and in 2 years the percentage of expenditures increased 3.5 times. However, the indicator of local budget expenditures on education has still not reached the level of 2014 (42.1\%).

In general, it can be noted that most of the local budgets of Ukraine are used to finance secondary, preschool and vocational education (since 2016 funding has been changed due to administrative decentralization, since 2017 financing has been provided by the central government (training of workers in professions of national importance) and local budgets (training of workers for regional labor markets).

It should also be noted that for the period from 2014 to 2020 there were changes in the percentage of own funds and borrowings of local budgets to finance education. Thus, if in 2014 education was financed mainly from own funds $-71.15 \%$ of the total funding, then in 2019-2020 you could see a roughly proportional distribution of local budgets own funds and borrowings to finance education (about $50 \%)$. However, the approach to financing the levels of education has not changed significantly: in terms of expenditures on financing education from the general consolidated budget of Ukraine, complete secondary education is a priority (48\%); then - vocational and higher education (about $24 \%$ ); the share of funding for postgraduate education is the lowest (only $1 \%$ ).

An effective mechanism for financing education at the present stage is the state 
targeted subventions, which were introduced in 2015 to cover the current expenditures for complete general secondary schools, to save the rests in local budgets for further usage with educational purposes. The main administrator of subventions is the corresponding ministry - Ministry of Education and Science of Ukraine, and their recipients and managers are local administrations and private secondary schools, which have a license to conduct educational activities.

The experience of using educational subventions has led to some amendments as to expansion of possibilities for their rests usage. It should be noted that the formation of educational subventions occurs in the first place, due to unexpended balances of current local budgets; secondly, as a result of the funds redistribution at the end of the year from the educational subvention reserve and from the funds provided for the financing of the temporarily occupied territories. The result of such redistribution is a significant filling of local budgets which, according to administrative order of local authorities, are not used for their intended purpose bypassing the educational sphere. Therefore, this situation requires the introduction of an effective control system, including that of the main administrator of the state subvention - the Ministry of Education and Science of Ukraine.

Nine types of targeted state subventions to local budgets were financed in 2019-2020. Such educational subventions as: "Educational subvention from the state budget to local budgets", "Subvention to provide quality, modern and affordable complete general secondary education of the New Ukrainian School", "Subvention to provide state support to people with special educational needs" have been financed for two years. In 2019 the following projects were financed: "Subvention for the creation and repair of existing sports facilities in secondary schools of all levels", "Subvention for the implementation of measures aimed at improving the quality of education", "Subvention for updating and renewal of material and technical base of professional (vocational) education institutions". In 2020 the following projects were financed: "Subvention for the implementation of the program "Potent school for better results", "Subvention for the establishment of educational and practical centers of new vocational education", "Subvention for improving social protection of certain 
categories of secondary school teachers".

If we analyze the target educational transfers, it can be argued that complete general secondary education still remains one of the priority areas to which most transfers are directed: to ensure the proper material and technical base of educational institutions (purchase of modern furniture, musical instruments, computer equipment, multimedia content, didactic materials); to train trainers-teachers for the New Ukrainian School, supervisors; to make and repair existing sports facilities at educational institutions; to improve the quality of education, etc.

In 2020 financing from the state budget was redistributed due to the announced COVID-19 pandemic. As a result, the amount of education funding decreased, which led to a fall in funding for educational programs of the corresponding ministry. Funding for 8 of the 15 programs was canceled: support of educational, scientific and sports programs; development of higher education institutions; state investment projects "Creation of the International Pilot Training Center on the basis of the National Aviation University", "Restoration of the old academic building of the Fraternal Monastery ensemble at 2 H.Skovoroda str., the Podilskyi district, Kyiv", "Restoration of Ivan Franko Lviv National University main building", "Construction of the International Student Meeting Center for Ukraine and the Republic of Poland"; support of priority directions of scientific researches and scientific and technical (experimental) developments in institutions of higher education; implementation of pedagogical staff certification, examination of educational programs of education quality assurance $[1$, c. 163].

Conclusions. All the above gives grounds to conclude that the state and level of funding for education in Ukraine are significantly influenced by objective and subjective factors. Today the country is in difficult socio-economic and political conditions caused by the global economic crisis of 2008, the events of 2013-2014 and the foreign aggression, which continues up to this day in Ukraine, as well as quarantine restrictions due to the declared in 2020 pandemic COVID -19 caused by coronavirus SARS-CoV-2. All these circumstances create obstacles for fully funding education by the Ukrainian government. Unfortunately, the state has still not reached 
the statutory percentage of education funding, although on average it still allocated about $6 \%$ of GDP.

The state continues to use general approaches in financing education, but at the same time, in recent years, an attempt has been made to introduce a new tool - the education subvention - intergovernmental transfer from the state budget to local budgets. This tool makes it possible to implement the budgetary principle of subsidiarity in financing education - the distribution of expenditures between state and local budgets. In addition, the principle of decentralization of management and financing of vocational (technical) education was introduced. Now the essential share of the educational subvention is aimed at raising the salaries of educational institutions staff, as well as at improving the material and technical base of educational institutions and enhancing the quality of education.

In general, I would like to note that despite attempts to change the approach to the distribution of funds for education in the consolidated budget of Ukraine, its funding is insufficient and not fully effective. We believe that in order to improve the financial and economic mechanism of education provision in the current environment, it is advisable to apply a project approach which is used in the development of priority national projects, and which allows to expand the scope of program-targeted management methods and contributes to key issues of socio-economic development.

\section{References}

1. Osvita v Ukraini: vyklyky ta perspektyvy. Informatsiino-analitychnyi zbirnyk. (2020). Ministerstvo osvity i nauky Ukrainy; Instytut osvitnoi polityky. Kyiv. 293 s. [Ukraina].

2. Osvitnia reforma: rezultaty ta perspektyvy. Informatsiino-analitychnyi zbirnyk. (2019). Ministerstvo osvity i nauky Ukrainy; Instytut osvitnoi analityky. Kyiv. 228 s. [Ukraina].

3. Postupna, O. V. Publichne upravlinnia rehionalnymy osvitnimy systemamy v Ukraini (2021). Kharkiv: TOV «Oberih». 400 s. [Ukraina]. 
4. Pro vyshchu osvitu. (2014). Zakon Ukrainy № 1556-VII. URL: http://zakon3.rada.gov.ua/laws/show/1556-18/page. [Ukraina].

5. Pro doshkilnu osvitu. (2001). Zakon Ukrainy № 2628-III. URL: http://zakon2.rada.gov.ua/laws/ show/2628-14. [Ukraina].

6. Pro osvitu. (2017). Zakon Ukrainy № 2145-VIII. URL: http://zakon2.rada.gov.ua/laws/show/2145-19. [Ukraina].

7. Pro pozashkilnu osvitu. (2020). Zakon Ukrainy № 1841-III. URL: https://zakon.rada.gov.ua/laws/show/1841-14\#Text. [Ukraina].

8. Pro profesiinu (profesiino-tekhnichnu) osvitu. (1998). Zakon Ukrainy № 103/98-VR. URL: https://zakon.rada.gov.ua/laws/show/103/98-\%D0\%B2\%D1\% 80\#Text. [Ukraina].

9. Reforma osvity ta nauky. Derzhavnyi sait Ukrainy. Uriadovyi portal. Yedynyi veb-portal orhaniv vykonavchoi vlady Ukrainy. URL: https://www.kmu.gov.ua/diyalnist/reformi/rozvitok-lyudskogo-kapitalu/reformaosviti. [Ukraina].

10. Finansovo-biudzhetna zvitnist. Ofitsiinyi sait Ministerstva osvity i nauky Ukrainy. URL: https://mon.gov.ua/ua/ministerstvo/diyalnist/finansovo-byudzhetnazvitnist. [Ukraina].

11. Finansuvannia osvity v krainakh svitu pid chas kryzy. (2021). Mizhnarodnyi viddil TsK Profspilky. URL: https://pon.org.ua/novyny/8831fnansuvannya-osvti-v-krayinah-svtu-pd-chas-krizi.html. [Ukraina].

12. Finansuvannia osvity v Ukraini. (2020). Osvitnia analityka Ukrainy: nauk.-prakt. zhurnal. Vyp. № 3 (10). Kyiv, DNU «Instytut osvitnoi analityky». S. 6681. URL: https://science.iea.gov.ua/wp-content/uploads/2020/12/66_81_Finansuv_ osvity.pdf. [Ukraina]. 